\title{
ORIENTASI LIFE SKIL DALAM KURIKULUM TINGKAT SATUAN PENDIDIKAN DENGAN PENDEKATAN SETS \\ (Science Environment Technology \& Society) PADA JENJANG PENDIDIKAN DASAR \& MENENGAH
}

\section{Listyono}

\section{A. Pendahuluan}

Kurikulum Tingkat Satuan Pendidikan (KTSP) adalah sebuah kurikulum operasional pendidikan yang disusun oleh dan dilaksanakan di masing-masing satuan pendidikan di Indonesia. KTSP secara yuridis diamanatkan oleh Undang-Undang Nomor 20 Tahun 2003 tentang Sistem Pendidikan Nasional dan Peraturan Pemerintah Republik Indonesia Nomor 19 Tahun 2005 tentang Standar Nasional Pendidikan. KTSP merupakan bagian yang tidak terpisahkan dari SI, namun pengembangannya diserahkan kepada sekolah agar sesuai dengan kebutuhan sekolah itu sendiri. Basis dari kurikulum ini adalah kompetensi yang harus dikuasai oleh siswa. Kompetensi merupakan pengetahuan, ketrampilan dan nilai-nilai yang direfleksikan dalam kebiasaan berfikir dan bertindak.

Pemberlakuan KTSP, sebagaimana yang ditetapkan dalam peraturan Menteri Pendidikan Nasional No. 24 Tahun 2006 tentang Pelaksanaan SI dan SKL, ditetapkan oleh kepala sekolah setelah memperhatikan pertimbangan dari komite sekolah. Dengan kata lain, pemberlakuan KTSP sepenuhnya diserahkan kepada sekolah, dalam arti tidak ada intervensi dari Dinas Pendidikan atau Departemen Pendidikan Nasional. Penyusunan KTSP selain melibatkan guru dan karyawan juga melibatkan komite sekolah serta bila perlu para ahli dari perguruan tinggi 
setempat. Dengan keterlibatan komite sekolah dalam penyusunan KTSP maka KTSP yang disusun akan sesuai dengan aspirasi masyarakat, situasi dan kondisi lingkungan dan kebutuhan masyarakat.

Kecakapan hidup merupakan orientasi pendidikan yang mensinergikan mata pelajaran menjadi kecakapan yang diperlukan seseorang,dimanapun ia berada,bekerja, atau tidak bekerja.

Kecakapan hidup (Life Skill) yaitu kemampuan dan keberanian untuk menghadapi problema kehidupan, kemudian secara proaktif dan kreatif, mencari serta menemukan solusi untuk mengatasi suatu permasalahan. Pengertian kecakapan hidup lebih luas dari keterampilan vokasional atau keterampilan untuk bekerja. Orang yang tidak bekerja, misalnya ibu rumah tangga atau orang yang sudah pensiun, tetap memerlukan kecakapan hidup. Seperti halnya orang yang bekerja, mereka juga menghadapi berbagai masalah yang harus dipecahkan. Orang yang sedang menempuh pendidikan pun memerlukan kecakapan hidup , karena mereka tentu juga memiliki permasalahannya sendiri.

Dengan bekal kecakapan hidup yang baik, diharapkan para lulusan akan mampu memecahkan problema kehidupan yang dihadapi, termasuk mencari atau menciptakan pekerjaan bagi mereka yang tidak melanjutkan pendidikannya. Untuk mewujudkan hal ini, perlu diterapkan prinsip pendidikan berbasis kompetensi yang tidak hanya berorientasi pada bidang akademik atau vokasional semata, tetapi juga memberikan bekal learning how to learn sekaligus learning how to unlearn, tidak hanya belajar teori, tetapi juga mempraktekkannya untuk memecahkan problema kehidupan sehari-hari (Bently, 2000).

Perkembangan kehidupan di masyarakat menuntut diberlakukannya pendidikan secara lebih terstruktur yang memungkinkan dihasilkannya lulusan yang sesuai dengan kebutuhan di masyarakat tersebut. Aktivitas pembelajaran di sekolah sebagai wujud nyata penterjemahan sistem pendidikan di sekolah pada umumnya dan di kelas pada khususnya seharusnya tidak mengkotak-kotakan secara kaku berbagai bahan kajian melalui tiap

126 Jurnal PHENOMENON, Volume 1 Nomor 1, Juli 2011 
mata pelajaran. Hal ini dimaksudkan agar hasil belajar di sekolah terasakan manfaatnya baik bagi peserta didik langsung maupun bagi masyarakat seeara luas. Standar Kompetensi (SK) dan Kompetensi Dasar (KD) yang dituangkan di dalam standar isi untuk mata pelajaran yang terpisah-pisah sebaiknya dimaknai bahwa pencapaiannya dapat ditempuh melalui pengintegrasian SK dan KD beberapa mata pelajaran ke dalam satu wadah pembelajaran. Salah satu model pembelajaran yang bisa ditempuh adalah melalui model pembelajaran sains, lingkungan, teknologi dan masyarakat (SETS).

Perkembangan sains dan teknologi serta dampaknya pada lingkungan dan masyarakat, menjadi semakin tidak terpisahkan dalam kehidupan manusia. Mengingat keterkaitan yang sangat erat antara lingkungan, teknologi, dan masyarakat dengan sains, maka sangat dimungkinkan untuk menggunakan keterkaitan tersebut sebagai cara pandang atau visi kita dalam melihat sesuatu. Oleh karena itu meniadakan keterkaitan keempat unsur tersebut menjadi tidak relevan dalam konteks pendidikan masa kini. Untuk mewujudkan proses pembelajaran yang mengembangkan konsep sains, dengan memperhatikan penggunaanya pada teknologi, dan dampaknya bagi lingkungan dan masyarakat, maka dikembangkanlah pendekatan Science, Environment, Technology, and Society (SETS) sebagai pilihan dalam proses pembelajaran yang ada. Selain memberi peluang kepada peserta didik untuk belajar secara kontekstual, pendekatan ini juga memberi peluang dikembangkannya life skills pada diri peserta didik. Oleh karena itu, sangat relevan jika visi serta pendekatan SETS digunakan dalam pembelajaran di sekolah. (Binadja,2001).

Sebagai visi, secara sengaja kita membawa pemikiran para peserta didik tentang keberadaan keempat unsur (SETS) serta berbagai implikasi yang terkandung atau tercakup di dalamnya ketika mereka "melihat" sesuatu. Dari sana diharapkan peserta didik dapat menghasilkan pemikiran atau gagasan-gagasan baru (inovatif) yang dapat dihasilkan dari hasil "penglihatan" itu sesuai dengan

kemampuan mereka di jenjang usia atau jenjang pendidi- 
kan yang mereka lewati dengan memadukan berbagai macam pengalaman hidup mereka, sehingga kemampuan dan keberanian untuk menghadapi problema kehidupan, kemudian secara proaktif dan kreatif, mencari serta menemukan solusi untuk mengatasinya suatu permasalahannya.

\section{B. Dasar Pemikiran Pengembangan Kurikulum}

Negara Indonesia memiliki sumber daya alam yang sangat besar dan yang seharusnya dapat dinikmati dengan baik sepanjang hayat. Maka diperlukan adanya sumber daya manusia yang menguasai kemampuan fisik, intelektual, social dan kredibilitas sehingga mampu mengaplikasikan ilmu pengetahuannya untuk kesejahteraan hidup. Hal ini penting perlunya mutu lulusan yang memiliki kompetensi yang mampu menguasai ketrampilan dan kecakapan standar internasional. Perlunya pengembangan kurikulum yang mampu menjembatani dan melayani kebutuhan akan mutu lulusan sesuai dengan kebutuhan.

Pengembangan kurikulum adalah istilah yang komprehensif, didalamnya mencakup: perencanaan, penerapan dan evaluasi. Perencanaan kurikulum adalah langkah awal membangun kurikulum ketika pekerja kurikulum membuat keputusan dan mengambil tindakan untuk menghasilkan perencanaan yang akan digunakan oleh guru dan peserta didik. Penerapan Kurikulum atau biasa disebut juga implementasi kurikulum berusaha mentransfer perencanaan kurikulum ke dalam tindakan operasional. Evaluasi kurikulum merupakan tahap akhir dari pengembangan kurikulum untuk menentukan seberapa besar hasil-hasil pembelajaran, tingkat ketercapaian program-program yang telah direncanakan, dan hasil-hasil kurikulum itu sendiri. Dalam pengembangan kurikulum, tidak hanya melibatkan orang yang terkait langsung dengan dunia pendidikan saja, namun di dalamnya melibatkan banyak orang, seperti : politikus, pengusaha, orang tua peserta didik, serta unsur - unsur masyarakat lainnya yang merasa berkepentingan dengan pendidikan.

Prinsip-prinsip yang akan digunakan dalam kegiatan 
pengembangan kurikulum pada dasarnya merupakan kaidahkaidah atau hukum yang akan menjiwai suatu kurikulum. Dalam pengembangan kurikulum, dapat menggunakan prinsip-prinsip yang telah berkembang dalam kehidupan sehari-hari atau justru menciptakan sendiri prinsip-prinsip baru. Oleh karena itu, dalam implementasi kurikulum di suatu lembaga pendidikan sangat mungkin terjadi penggunaan prinsip-prinsip yang berbeda dengan kurikulum yang digunakan di lembaga pendidikan lainnya, sehingga akan ditemukan banyak sekali prinsip-prinsip yang digunakan dalam suatu pengembangan kurikulum. Dalam hal ini, Nana Syaodih Sukmadinata (1997) mengetengahkan prinsip-prinsip pengembangan kurikulum yang dibagi ke dalam dua kelompok : (1) prinsip - prinsip umum : relevansi, fleksibilitas, kontinuitas, praktis, dan efektivitas; (2) prinsipprinsip khusus : prinsip berkenaan dengan tujuan pendidikan, prinsip berkenaan dengan pemilihan isi pendidikan, prinsip berkenaan dengan pemilihan proses belajar mengajar, prinsip berkenaan dengan pemilihan media dan alat pelajaran, dan prinsip berkenaan dengan pemilihan kegiatan penilaian. Sedangkan Asep Herry Hernawan dkk (2002) mengemukakan lima prinsip dalam pengembangan kurikulum, yaitu :

1. Prinsip relevansi; secara internal bahwa kurikulum memiliki relevansi di antara komponen-komponen kurikulum (tujuan, bahan, strategi, organisasi dan evaluasi). Sedangkan secara eksternal bahwa komponen-komponen tersebutmemiliki relevansi dengan tuntutan ilmu pengetahuan dan teknologi (relevansi epistomologis), tuntutan dan potensi peserta didik (relevansi psikologis) serta tuntutan dan kebutuhan perkembangan masyarakat (relevansi sosilogis).

2. Prinsip fleksibilitas; dalam pengembangan kurikulum mengusahakan agar yang dihasilkan memiliki sifat luwes, lentur dan fleksibel dalam pelaksanaannya, memungkinkan terjadinya penyesuaian-penyesuaian berdasarkan situasi dan kondisi tempat dan waktu yang selalu berkembang, serta kemampuan dan latar bekang 
peserta didik.

3. Prinsip kontinuitas; yakni adanya kesinambungan dalam kurikulum, baik secara vertikal, maupun secara horizontal. Pengalaman-pengalaman belajar yang disediakan kurikulum harus memperhatikan kesinambungan, baik yang di dalam tingkat kelas, antar jenjang pendidikan, maupun antara jenjang pendidikan dengan jenis pekerjaan.

4. Prinsip efisiensi; yakni mengusahakan agar dalam pengembangan kurikulum dapat mendayagunakan waktu, biaya, dan sumber-sumber lain yang ada secara optimal, cermat dan tepat sehingga hasilnya memadai.

5. Prinsip efektivitas; yakni mengusahakan agar kegiatan pengembangan kurikulum mencapai tujuan tanpa kegiatan yang mubazir, baik secara kualitas maupun kuantitas.

Terkait dengan pengembangan Kurikulum Tingkat Satuan Pendidikan, terdapat sejumlah prinsip-prinsip yang harus dipenuhi, yaitu :

1. Berpusat pada potensi, perkembangan, kebutuhan, dan kepentingan peserta didik dan lingkungannya. Kurikulum dikembangkan berdasarkan prinsip bahwa peserta didik memiliki posisi sentral untuk mengembangkan kompetensinya agar menjadi manusia yang beriman dan bertakwa kepada Tuhan Yang Maha Esa, berakhlak mulia, sehat, berilmu, cakap, kreatif, mandiri dan menjadi warga negara yang demokratis serta bertanggung jawab. Untuk mendukung pencapaian tujuan tersebut pengembangan kompetensi peserta didik disesuaikan dengan potensi, perkembangan, kebutuhan, dan kepentingan peserta didik serta tuntutan lingkungan.

2. Kurikulum dikembangkan dengan memperhatikan keragaman karakteristik peserta didik, kondisi daerah, dan jenjang serta jenis pendidikan, tanpa membedakan agama, suku, budaya dan adat istiadat, serta status sos- 
ial ekonomi dan gender. Kurikulum meliputi substansi komponen muatan wajib kurikulum, muatan lokal, dan pengembangan diri secara terpadu, serta disusun dalam keterkaitan dan kesinambungan yang bermakna dan tepat antarsubstansi.

3. Tanggap terhadap perkembangan ilmu pengetahuan, teknologi, dan seni. Kurikulum dikembangkan atas dasar kesadaran bahwa ilmu pengetahuan, teknologi dan seni berkembang secara dinamis, dan oleh karena itu semangat dan isi kurikulum mendorong peserta didik untuk mengikuti dan memanfaatkan secara tepat perkembangan ilmu pengetahuan, teknologi, dan seni.

4. Relevan dengan kebutuhan kehidupan. Pengembangan kurikulum dilakukan dengan melibatkan pemangku kepentingan (stakeholders) untuk menjamin relevansi pendidikan dengan kebutuhan kehidupan, termasuk di dalamnya kehidupan kemasyarakatan, dunia usaha dan dunia kerja. Oleh karena itu, pengembangan keterampilan pribadi, keterampilan berpikir, keterampilan sosial, keterampilan akademik, dan keterampilan vokasional merupakan keniscayaan.

5. Menyeluruh dan berkesinambungan. Substansi kurikulum mencakup keseluruhan dimensi kompetensi, bidang kajian keilmuan dan mata pelajaran yang direncanakan dan disajikan secara berkesinambungan antarsemua jenjang pendidikan.

6. Belajar sepanjang hayat. Kurikulum diarahkan kepada proses pengembangan, pembudayaan dan pemberdayaan peserta didik yang berlangsung sepanjang hayat. Kurikulum mencerminkan keterkaitan antara unsurunsur pendidikan formal, nonformal dan informal, dengan memperhatikan kondisi dan tuntutan lingkungan yang selalu berkembang serta arah pengembangan manusia seutuhnya.

7. Seimbang antara kepentingan nasional dan kepentingan daerah. Kurikulum dikembangkan dengan memperha- 
tikan kepentingan nasional dan kepentingan daerah untuk membangun kehidupan bermasyarakat, berbangsa dan bernegara. Kepentingan nasional dan kepentingan daerah harus saling mengisi dan memberdayakan sejalan dengan motto Bhineka Tunggal Ika dalam kerangka Negara Kesatuan Republik Indonesia.

Pemenuhan prinsip-prinsip di atas itulah yang membedakan antara penerapan satu Kurikulum Tingkat Satuan Pendidikan dengan kurikulum sebelumnya, yang justru tampaknya sering kali terabaikan. Karena prinsip-prinsip itu boleh dikatakan sebagai ruh atau jiwanya kurikulum

Dalam mensikapi suatu perubahan kurikulum, banyak orang lebih terfokus hanya pada pemenuhan struktur kurikulum sebagai jasad dari kurikulum . Padahal jauh lebih penting adalah perubahan kutural (perilaku) guna memenuhi prinsipprinsip khusus yang terkandung dalam pengembangan kurikulum.

\section{SETS Dalam Kurikulum Tingkat Satuan Pendidikan}

Dalam kehidupan yang dikendalikan oleh teknologi serba digital, keterkaitan sains dan teknologi serta dampaknya pada lingkungan dan masayarakat perlu lebih ditekankan pada tiap sudut pembelajaran. Pendidikan bervisi SETS tidak hanya memperhatikan isu dan masyarakat serta lingkunngan, namun lebih menitikberatkan cara melakukan sesuatu untuk kepentingan masyarakat serta kelestarian terjaga sementara kepentingan lain terpenuhi. Dalam membuat konsep sains berguna dalam teknologi untuk memenuhi keperluan masyarakat, yang berakibat pada permasalahan lingkungan. Pengajaran SETS atau Salingtemas membantu siswa untuk mengetahui sains, perkembangannya dan bagaimana perkembangan sains dapat mempengaruhi lingkungan, teknologi, dan masyarakat secara timbal balik (Binadja,2006). Visi SETS merupakan cara pandang yang memungkinkan kita untuk melihat, bahwa di dalam sesuatu yang kita kenal, terdapat saling keterkaitan antara konsep-kon- 
sep sains, lingkungan, teknologi, dan masyarakat, sebagai satu kesatuan yang integratif.

Pendidikan bervisi SETS memberi peluang siswa untuk berpikir komperhensif dengan mengintegrasikan berbagai pengetahuan yang telah dimiliki (Binadja,2000). Tujuan pembelajaran berwawasan SETS baru dapat tercapai saat guru dan siswa berperan bersama didalamnya (Binadja, 2001). Guru harus dapat mencari informasi / berita yang berkembang di masyarakat untuk diangkat pada saat membahas materi yang berkaitan. Binadja (2001) menyebutkan contoh ciri pembelajaran berpendekatan SETS pada mata pelajaran biologi antara lain :

1. Memberi pembelajaran konsep Biologi yang diinginkan

2. Murid diajak melihat teknologi berkaitan konsep yang dipelajari serta memanfaatkan konsep Biologi ke bentuk teknologi untuk kepentingan masyarakat.

3. Murid diminta berpikir tentang berbagai kemungkinan akibat (positif/negatif) yang dapat terjadi dalam proses pentransferan Biologi ke dalam bentuk teknologi.

4. Murid diminta menjelaskan keterkaitan unsur sains yang diperbincangkan dengan unsur lain dalam SETS yang saling mempengaruhi.

5. Murid diajak mempertimbangkan manfaat/kerugian penggunaan konsep sains Biologi tersebut bila diubah dalam bentuk teknologi.

6. Murid diajak mencari alternatif pengentasan terhadap kerugian yang mungkin timbul oleh penerapan sains ke bentuk teknologi terhadap lingkungan dan masyarakat (mencari bentuk teknologi yang lebih baik).

Dalam konteks konstruktivisme, murid diajak berbincang tentang SETS berkaitan dengan konsep sains yang dibelajarkan dari berbagai macam arah dan berbagai macam titik awal tergantung pengetahuan dasar yang dimiliki oleh siswa. Menurut Nurwati (2000), pendekatan SETS dalam pembelajaran Biologi akan memotivasi siswa menjadi lebih tertarik terhadap bahasan yang sedang dipelajarinya karena dikaitkan dengan hal nyata 
yang terjadi dalam kehidupan sehari-hari.

\section{Kurikulum Tingkat Satuan Pendidikan dan Ketrampilan Hidup}

Ketrampilan hidup, dapat ditumbuhkan melalui pengembangan kurikulum, salah satu tujuan pendidikan nasional adalah agar lulusan memiliki keunggulan kompetitif dan komparatif sesuai dengan standar mutu kelulusan, baik nasional maupun internasional. Kompetensi yang tercantum dalam kurikulum tingkat satuan pendidikan yang tertera dalam setiap silabus mata pelajaran menjamin tumbuhnya keimanan dan ketakwaan terhadap Tuhan Yang Maha Esa, yang meliputi penguasaan ketrampilan hidup, baik akademik, sosial, serta pengembangan kepribadian. Dari pejabaran tiap standar kompetensi menjadi kompetensi dasar yang tercapai melalui setiap indikatornya. Dari tiap indikator inilah proses pemantauan tercapainya kecakapan hidup terevaluasi, karena pengukuran indikator melalui kata kerja operasional yang dapat teramati dan terukur. Contoh konkrit, siswa dapat menganalisa, menjelaskan, mendiskusikan, mempraktekkan, melaksanakan. Dalam tiap kondisi seperti inilah kompetensi yang beintegrasi dengan life skil/kecakapan hidup terukur.

\section{E. Kesimpulan}

Dari pembahasan di atas dapat di simpulkan :

1. Kompetensi dalam kurikulum tingkat satuan pendidikan dapat tercapai asalkan ada kejelasan dengan memperhatikan keutuhan dan keterintegrasian pengetahuan yang mencukupi sesua tujuan yang dikehendaki.

2. Dalam pengembangan kompetensi menjadi silabus perlu penekanan tujuan di setiap indikatornya, sehingga integrasi life skill apa yang ingin di capai dapat terukur jelas.

3. Untuk memudahkan pencapaian unsur SETS, pengintegrasian pada setiap materi pokok secara utuh.

4. Pelaksanaan pembelajaran dalam pengintegrasian ini tidak harus secara konvensional. 


\section{DAFTAR PUSTAKA}

Binadja, Achmad (2001) Pendidikan Berwawasan SETS (Sciense, Environment,Technology, and Society) Dalam Managemen Pendidikan Berbasis Sekolah, Makalah disajikan dalam seminar, Guntur, Purwodadi 22 November 2000.

Binadja, Achmad (2002). Pendidikan Bervisi SETS (Science, Environment, Technology and Society) Implikasi Kurikulum Berbasis Kompetensi Pada Pendidikan Dasar dan Menengah. Makalah Seminar Nasional Pendidikan Berbasis Kompetensi UNNES Semarang 27 Februari 2002.

Puskur, Balitbang,Depdiknas (2002) Kurikulum Berbasis Kompetensi.

Listyono, (2003) Model Pembelajaran Penemuan Konsep Dalam Meningkatkan Aktifitas Dengan Pendekatan SETS bervisi Qur'an dan Hadist.

Swara Ditpertais: No. 17 Th. II, 18 Oktober 2004, Pengembangan Kurikulum Berbasis Kompetensi

I Made Alit Mariana,Eddy Hidayat (2000). Hakekat Pendekatan SETS dalam Pembelajaran Sains. Bandung : PPG IPA.

Nicholas, J (19995). Learning And Skills. London and New York : Longman.

Novak,D. And Gowin (1986). Learning How To Learn. Sydney : Departement of Education New York State College of Agriculture and Life Sciences Cornell University. 